\title{
Changes in the concentration of selected metals in sediments of the River Chotla in northwest Poland in its section affected by various anthropogenic factors
}

\author{
Małgorzata Włodarczyk, Hanna Siwek, Anna Buchwał, Edyta Rafacz
}

Department of General and Ecological Chemistry, Faculty of Environmental Management and Agriculture, West Pomeranian University of Technology in Szczecin, Słowackiego 17, 71-434 Szczecin, Poland, e-mail: malgorzata.wlodarczyk@zut.edu.pl (corresponding author)

\begin{abstract}
The purpose of the paper was to assess the changes in the concentration of selected metals in the bottom sediment and interstitial water of the River Chotla in northwest Poland. The research was conducted on the river section flowing through Zaspy Małe and a salmonid fish breeding farm. Samples of water and bottom sediment were taken in four control and measurement points, located above and below the village and on a backwater above the trouteries and below the fish breeding ponds. The $\mathrm{pH}$ and the concentration of the metals potassium, iron, calcium, manganese and zinc were determined in the water and sediment samples. The lowest concentrations of the metals were found in the samples collected above and below Zaspy Małe, while the highest concentrations of metals in the water and sediment were found in the samples taken in the backwater, above the fish breeding ponds. Exceptions were calcium and potassium, with the highest concentrations of metals in the water being found in the samples taken below the fish breeding ponds. The content of metals in sediments of the analysed section of the River Chotla was mainly determined by the content of organic matter, which varied as it is dependent on water accumulation processes and the operation of nearby fishery facilities. The slightly alkaline pH facilitated long-lasting accumulation of metals in sediments.
\end{abstract}

Key words: interstitial water, bottom sediment, metal content, river, breeding ponds

\section{Introduction}

Bottom sediments are essential elements of the aquatic ecosystem and act as a kind of buffer for many macro- and micro components, as well as toxic substances. These substances are bound in bottom sediments due to processes of precipitation, sedimentation and sorption, and released to the water phase as a result of mineralisation, dissolution, and desorption. The balance is set between the content of the elements in bottom sediments and their concentration in water near bottom sediments. This balance can be shifted depending on the changes in biogeochemical conditions of water reservoirs. Such changes are connected with natural and anthropogenic processes which occur in a water reservoir as well as within its catchment area. As a result, the chemical composition of unconsolidated surface layers of bottom sediments tends to change continually, particularly in terms of pollutants including metals which are bound by organic matter.
The composition of bottom sediments in agricultural catchments is to a large extent determined by catchment use and management (Szyperek 2005a, 2005b; Skwierawski 2003). Agricultural pollution is mainly territorial, yet point sources of pollution connected with livestock farming and resulting from negligent storage of livestock manure additionally affect water quality. In rural areas, water quality decreases as a consequence of an increase in plant and livestock production within the catchment area. However, the situation is different when it comes to fishponds: shallow water reservoirs which, apart from being used for fish farming, constitute important hydrological objects which increase the reservoirs of surface and ground waters within the catchment area. Intense metabolic processes and high energy flow in such water reservoirs facilitate water purification processes comparable to that of a class III wastewater treatment plant (Kosturkiewicz and Muratowa 1993). Many authors acknowledge the decrease in the concentration of bio- 
genic compounds, mainly nitrogen and phosphorus, in water ebbing from fishponds (Knösche et al. 2000; Kanclerz 2005; Orlik and Obroślak 2005). Various research sources fail to indicate that fishponds have the capability of purifying water from metals. Studies which show that bottom sediments in waters downriver from agricultural farms are polluted with zinc and copper, mainly from faeces and animal fodder (Brooks and Mahnken 2003; Schendel et al. 2004), concern mainly waters adjacent to mariculture farms.

The aim of the present paper is to evaluate the changes in selected chemical indices of bottom sediment quality in the River Chotla stretch influenced by strong anthropogenic factors - Zaspy Małe town and the salmonid farm. The study includes the analysis of changes in the content of organic matter, $\mathrm{pH}$ as well as selected bio elements of a metallic nature.

\section{Material and methods}

The River Chotla is a small watercourse $38 \mathrm{~km}$ in length and with a catchment area of $114 \mathrm{~km}^{2}$, located entirely in West Pomeranian Voivodeship, Białogard County in northwest Poland. The river valley is a part of the European Ecological Network Nature 2000 ("Valley of the River Radwia, the River Chotla and the River Chociel”, PLH 320010). This document mentions salmonid farms as one of the possible threats to the environment. The research was conducted on the river section near Zaspy Małe town, located $6.6 \mathrm{~km}$ upriver from the point at which it joins the River Radew. Samples of water and bottom sediments were taken in four measuring and control points located upstream - S1 $\left(\lambda=16^{\circ} 09^{\prime} 26^{\prime \prime} ; \varphi=54^{\circ} 01^{\prime} 50^{\prime \prime}\right)$ - and downstream - S2 $\left(\lambda=16^{\circ} 09^{\prime} 24^{\prime \prime} ; \varphi=54^{\circ} 01^{\prime} 55^{\prime \prime}\right)$ - from the town, as well as near the water accumulation area upriver from the salmonid farm - S3 ( $\left.\lambda=16^{\circ} 09^{\prime} 25^{\prime \prime} ; \varphi=54^{\circ} 02^{\prime} 03^{\prime \prime}\right)$ and water outflow from fishponds - S4 $\left(\lambda=16^{\circ} 09^{\prime} 29^{\prime \prime}\right.$; $\varphi=54^{\circ} 02^{\prime} 13^{\prime \prime}$ ) (Fig. 1). The samples were taken four times in the growing season in April, June, August and October. The samples were collected from the surface bottom layer with the use of a core sampler designed to collect undisturbed samples of bottom sediments - made by KC-Denmark (diameter $7 \mathrm{~cm}$ and length $1 \mathrm{~m}$ ). Only the surface layer of the sediment, approximately $10 \mathrm{~cm}$ thick, was collected for analysis. After the samples were centrifuged and the interstitial waters were separated, the collected samples were dried at room temperature. Air dried sediment was ground in a mortar and sieved through a $2 \mathrm{~mm}$ sieve. Sedi- ment fractions with a grain diameter less than $2 \mathrm{~mm}$ were chemically analysed.

The concentration of selected metals, potassium, iron, calcium, magnesium, manganese and zinc, as well as $\mathrm{pH}$, were determined in the samples of interstitial water and sediment. Total metallic content was determined after mineralisation of the samples in a mixture of acids $\mathrm{HNO}_{3}$ and $\mathrm{HClO}_{4}$. The measurement was taken by means of emission $(\mathrm{K}, \mathrm{Ca})$ and absorption (other metals) atomic spectrometry with the use of a spectrometer Solaar S (ThermoElemental). Organic carbon content (OC) in sediment samples was determined with Orlow and Grindel's method. The content

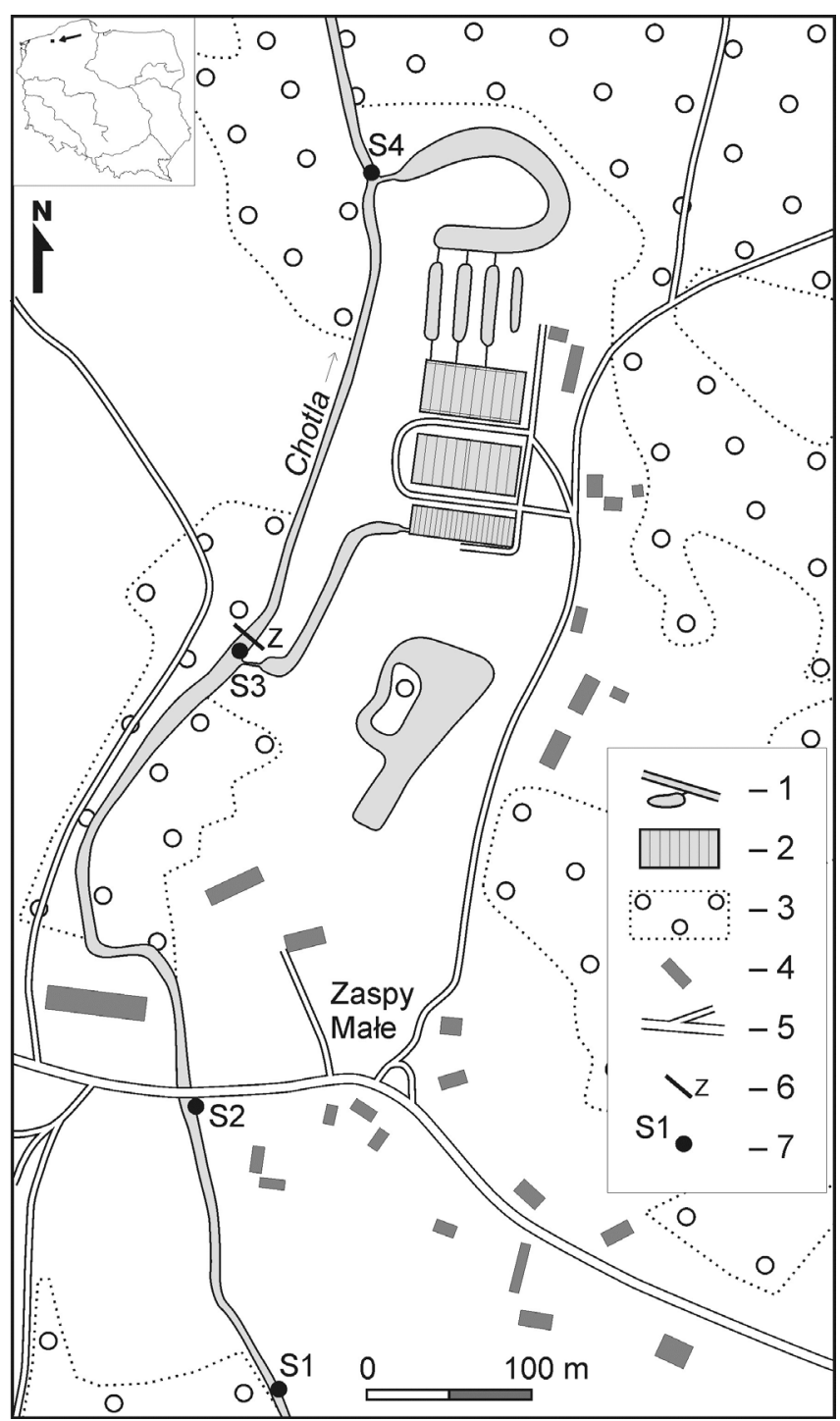

Fig.1. Sampling site location: 1 - surface water, 2 - fish breeding ponds, 3 - forest, 4 - building, 5 - road, 6 - water gate on the River Chotla, 7 - measuring point 
of organic carbon was calculated for the content of the organic substance by multiplying it by 1.724 . The determination was conducted with the use of a bifascicular spectrophotometer UV/VIS 8500 (Techcomp).

The obtained results were subject to statistical analysis. The differences between mean content of the analysed elements taken from various points of the river were analysed with the use of one-way variance analysis following the assessment of the distribution of the analysed contents against their normal distribution (Shapiro-Wilk's test) and the test for homogeneity of variances (Levene's test). The results of the tests show the lack of grounds for the exclusion of the hypothesis on the normality and homogeneity of the analysed data. The significance of the differences between mean content of the analysed elements was assessed with the use of Tukey's post-hoc test. The linear regression analysis was used for selected parameters of water quality and sediment, and the significance of Pearson's linear correlation coefficients was assessed with the use of a t test. The statistical analysis of the data was conducted at the significance level $\alpha=0.05$.

\section{Results and discussion}

Bottom sediments obtained from the aforementioned section of the River Chotla were slightly acidic $\left(5.6<\mathrm{pH}_{(\mathrm{KCL})}<6.5\right)$; the lowest $\mathrm{pH}_{\mathrm{KCl}}$ was determined in the bottom sediment taken from the water accumulation area (S3) upriver from the fishponds (Table $1)$. The change in sediment $\mathrm{pH}$, which reached neutral $\left(6.6<\mathrm{pH}_{(\mathrm{KCL})}<7.2\right)$, was found at the measuring point downriver from the fishponds (S4). $\mathrm{pH}$ measured in mid-sediment water was comparable to that of slightly alkaline waters.

The analysed sediments varied in terms of organic matter content, which increased downriver from 1.68 at the S1 measuring point to $4.64 \%$ at the S4 measuring point. Consequently, the classification of sediment samples taken at measuring points S1 and S2 is mineral sediment, and the samples obtained from measuring point $\mathrm{S} 4$ are humic mineral sediment. A comparable content of organic matter was found in riverine sediments of the Barycz River catchment from 0.3 to 9.1\% (Marek 1989), and in the River Mielnica watercourse, where the content of organic carbon ranged from 7.5 to $39.1 \mathrm{~g} \mathrm{~kg}^{-1}$ (Licznar et al. 2005). Organic carbon content in sediments obtained from the water accumulation area (S3) was more than ten times higher than that in sediment samples obtained from other measuring points $-187.9 \mathrm{~g} \mathrm{C} \mathrm{kg}^{-1}$ dry mass, which corresponds to $32.39 \%$ organic matter and allows classification of this sediment as organic. In the area of water accumulation water flow is slower than in other parts of the river, which results in accumulation of organic substances. Organic matter content in sediment samples of this river section was significantly higher than in sediment samples obtained from Krempna storage reservoir of the River Wisłoka and from Zasławce storage reservoir of the River Dłubnia, where the values ranged from 1.16 to $3.52 \%$ (Jasiewicz and Baran 2006). Significant changes in organic matter content of sediments obtained from the River Chotla were found in the areas downriver from the fishponds (S4). Comparison of such values with mean organic matter content in sediments from S1 and S2 measuring points indicates a twofold increase. The increase in organic matter content in the tributary area from the fishponds is also noted by Szymański et al. (2012) in his study of bottom sediments in Lake Widryńskie. Changes in organic matter content in bottom sediments along the River Chotla (Table 2) were accompanied by changes in the content of analysed metals as well as values of the accumulation index (Fig. 2). Metal content was the lowest in sediments taken from the area up- (S1) and downriver (S2) from Zaspy Małe town. Lack of significant differences in metal content between the two areas indicates that domestic wastewater from the town does not have a significant influence on pollution with the analysed metals. The content of

Table 1 . Selected physical and chemical parameters of investigated waters and sediments

\begin{tabular}{cccccc}
\hline \multirow{2}{*}{ Sampling site } & \multirow{2}{*}{$\mathrm{pH}$ of water } & \multicolumn{4}{c}{ Bottom sediment } \\
\cline { 3 - 6 } & & $\mathrm{pH}_{\mathrm{H} 2 \mathrm{O}}$ & $\mathrm{pH}_{\mathrm{KCl}}$ & $\mathrm{C}_{\text {org. }}$ [ $\mathrm{g} \mathrm{kg}^{-1}$ d.m.] & organic matter [\%] \\
\hline $\mathrm{S} 1$ & 7.63 & 6.45 & 6.22 & 9.7 & 1.68 \\
\hline $\mathrm{S} 2$ & 7.56 & 6.58 & 6.22 & 17.3 & 2.99 \\
\hline $\mathrm{S} 3$ & 7.55 & 6.52 & 5.81 & 187.9 & 32.39 \\
\hline $\mathrm{S} 4$ & 7.52 & 6.87 & 6.78 & 26.9 & 4.64
\end{tabular}

S1 - above the village; S2 - below the village; S3 - on a backwater above fish breeding ponds; S4 - below the fish breeding ponds 


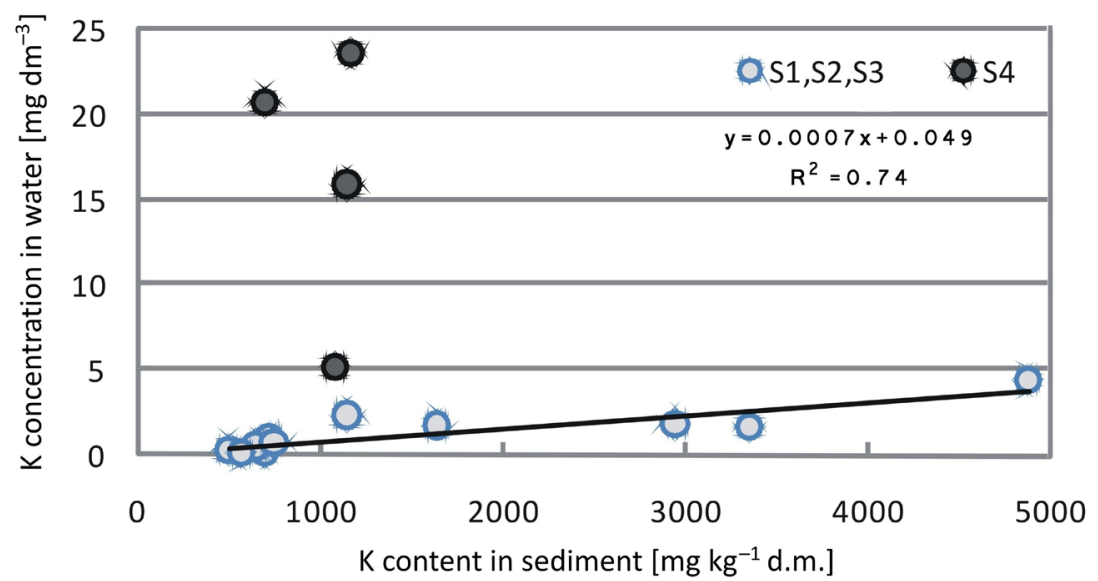

Fig.2. Relationships between content of potassium in bottom sediment and interstitial water of the investigated part of the River Chotla

Table 2. Mean concentration of examined metals in the water and bottom sediments

\begin{tabular}{|c|c|c|c|c|c|c|}
\hline \multirow{2}{*}{ Sampling site } & \multirow{2}{*}{ Statistical parameter } & \multicolumn{5}{|c|}{ Metal } \\
\hline & & $\mathrm{Ca}$ & $\mathrm{K}$ & $\mathrm{Fe}$ & $\mathrm{Mn}$ & $\mathrm{Zn}$ \\
\hline \multicolumn{7}{|c|}{ Concentration in interstitial water $\left[\mathrm{mg} \mathrm{dm}^{-3}\right]$} \\
\hline \multirow{2}{*}{ S1 } & average & $0.65^{\mathrm{a}}$ & $0.96^{\mathrm{a}}$ & $5.84^{a}$ & $2.225^{\mathrm{a}}$ & $0.108^{a}$ \\
\hline & SD & 1.31 & 0.96 & 5.54 & 1.034 & 0.170 \\
\hline \multirow{2}{*}{$\mathrm{S} 2$} & average & $0.57^{\mathrm{a}}$ & $0.27^{a}$ & $4.77^{\mathrm{a}}$ & $1.453^{\mathrm{a}}$ & $0.050^{\mathrm{a}}$ \\
\hline & SD & 0.91 & 0.31 & 2.24 & 0.614 & 0.047 \\
\hline \multirow{2}{*}{ S3 } & average & $0.13^{a}$ & $2.33^{a}$ & $2.96^{\mathrm{a}}$ & $1.973^{\mathrm{a}}$ & $0.053^{a}$ \\
\hline & SD & 0.27 & 1.32 & 2.38 & 0.987 & 0.061 \\
\hline \multirow{2}{*}{ S4 } & average & $13.94^{b}$ & $16.31^{\mathrm{b}}$ & $8.81^{a}$ & $1.420^{\mathrm{a}}$ & $0.023^{\mathrm{a}}$ \\
\hline & SD & 5.04 & 8.10 & 7.63 & 0.635 & 0.045 \\
\hline \multicolumn{7}{|c|}{ Content in bottom sediment [\%] } \\
\hline \multirow{2}{*}{ S1 } & average & $0.03^{a}$ & $0.08^{\mathrm{a}}$ & $0.49^{a}$ & $0.022^{a}$ & $0.002^{\mathrm{a}}$ \\
\hline & SD & 0.02 & 0.03 & 0.14 & 0.089 & 0.001 \\
\hline \multirow{2}{*}{$\mathrm{S} 2$} & average & $0.03^{a}$ & $0.06^{\mathrm{a}}$ & $0.44^{a}$ & $0.020^{\mathrm{a}}$ & $0.002^{\mathrm{a}}$ \\
\hline & SD & 0.02 & 0.01 & 0.13 & 0.011 & 0.001 \\
\hline \multirow{2}{*}{ S3 } & average & $0.63^{\mathrm{b}}$ & $0.32^{\mathrm{b}}$ & $3.22^{b}$ & $0.228^{b}$ & $0.010^{\mathrm{a}}$ \\
\hline & SD & 0.28 & 0.13 & 1.19 & 0.109 & 0.004 \\
\hline \multirow{2}{*}{ S4 } & average & $0.16^{c}$ & $0.10^{c}$ & $0.59^{a}$ & $0.016^{a}$ & $0.003^{a}$ \\
\hline & SD & 0.14 & 0.02 & 0.01 & 0.037 & 0.001 \\
\hline
\end{tabular}

calcium and potassium was comparable to that in sediments of small water reservoirs in the Olsztyńskie lake region - from 230 to $2960 \mathrm{mg} \mathrm{Ca} \mathrm{kg}^{-1}$ dry mass (Szyperek 2005b), and from 210 to $6440 \mathrm{mg} \mathrm{K} \mathrm{kg}^{-1}$ dry mass (Szyperek 2005a) respectively. The content of manganese was comparable to that in bottom sediments of the River Mielnica, which is from 164 to $2207 \mathrm{mg} \mathrm{Mn} \mathrm{kg}{ }^{-1}$ dry mass. The content of zinc and iron in sediments in the River Chotla was relatively low and amounted to half that in the River Mienica, which was 42.0 to 70.5 mg Zn kg-1 dry mass and 1015 to 34420 mg Fe kg-1 dry mass respectively (Licznar et al. 2005).

The content of analysed metals was the highest in samples of sediments taken from the water accumu- 
lation area upriver from the salmonid farm (S3). The content of organic substances in samples taken from that area was ten times higher and calcium content was approximately eighteen times higher; the content of other metals was several times higher. Such marked changes in metal concentration were not observed for interstitial water, with the exception of potassium, the concentration of which was eight times higher in samples taken from the water accumulation area upriver from the salmonid farm (S3). Significant changes in metal concentrations were observed in mid-sediment waters downriver from the fishponds (S4). The comparison of concentrations in measuring points $\mathrm{S} 1$ and S2 with their mean values shows a ten-fold increase in calcium and potassium concentrations, as well as a two-fold increase in iron concentration. In all measuring points the concentration of potassium in interstitial waters was positively correlated with the content of this element in sediment (Fig. 2). Such correlation was not found in measuring points downriver from the fishponds. The analysis of the variability of potassium concentration in interstitial waters and in sediment (Fig. 2) shows that the analysed fishponds are sources of potassium pollution. The analysis did not find any significant effect of fishery on the changes in the content of the analysed metals in sediment, with the exception of calcium, the content of which in sediments downriver from the fishponds was five times higher.
In order to characterise the processes of metal accumulation in analysed sediments, an accumulation index was calculated (Fig. 3): the ratio of metal content in sediment to its concentration in mid-sediment water. For all analysed metals the index was highest in the water accumulation area. The highest values were recorded for calcium (45910) and iron (10860); for the remaining metals the values were comparable and within the range from 1159 for manganese to 1938 for zinc. The comparison of accumulation index values in measuring points S2 and S3 showed that the content of calcium was almost one hundred times higher in the area of water accumulation, and the content of other metals was ten times higher. However, this was not the case with potassium: there was a two-fold decrease in the values of the accumulation index for the water accumulation area, which points to the significant influence of organic matter content on metal binding in sediment. Unlike other analysed metals, potassium just as other monovalent cations, does not form complex bonds with organic matter (Sapek 2001). The highest values of the accumulation index in samples obtained from the water accumulation area can result from the fact that the analysis was conducted during the growing season, when biological processes are intense. The studies of the influence of a storage reservoir on limiting calcium migration showed that $83 \%$ of calcium deposited in the reservoir undergoes retention in the growing season (Koc and Duda 2009).

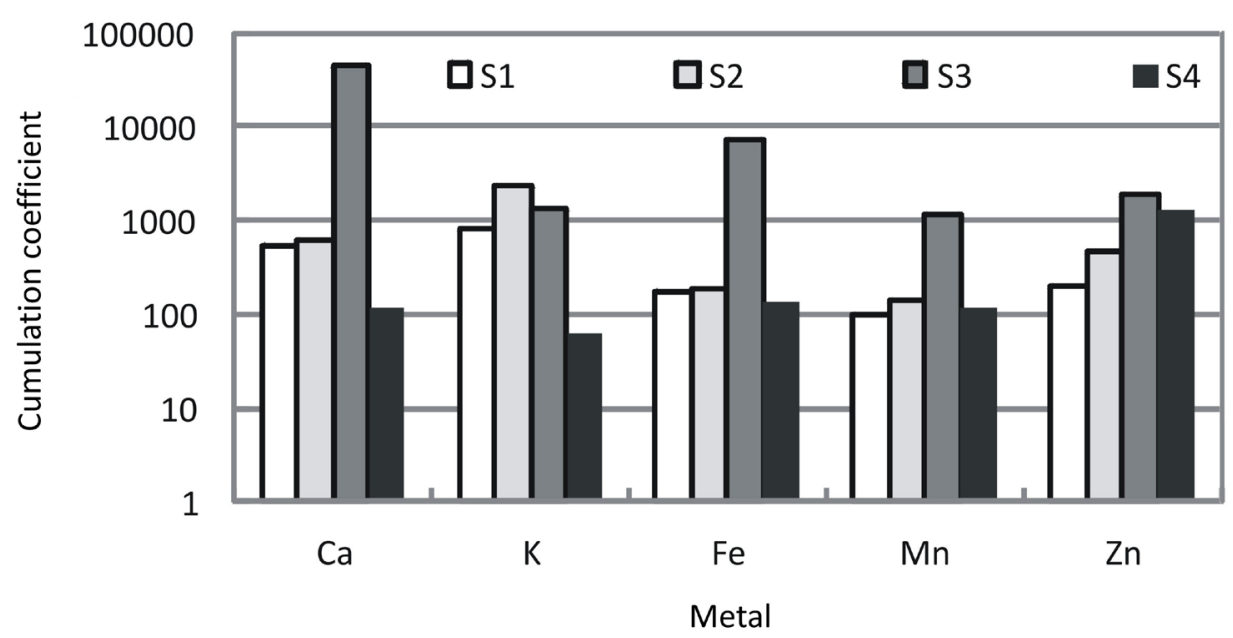

Fig. 3. Changes in the coefficient of metal cumulation in the measurement sites 


\section{Conclusion}

The highest content of the analysed metals in bottom sediments of the River Chotla was found in samples taken from water accumulation areas upriver from the fishponds. Due to water accumulation, the content of calcium was roughly eighteen times higher and the content of potassium, iron, manganese and zinc was several times higher.

Fishponds caused a significant increase in the concentration of calcium and potassium in mid-sediment waters. The analysis did not show any significant relationship between fishery and changes in metal content in sediments, with the exception of calcium.

The content of metals in sediments of the analysed section of the River Chotla was mainly determined by the content of organic matter, which varied as it is dependent on water accumulation processes and the operation of nearby fishery facilities. The slightly alkaline $\mathrm{pH}$ facilitated long-lasting accumulation of metals in sediments.

\section{References}

Brooks K.M., Mahnken C.V.W., 2003, Interactions of Atlantic salmon in the Pacific Northwest environment III. Accumulation of zinc and copper, Fish. Res. 62, 295-305.

Jasiewicz C., Baran A., 2006, The content of heavy metals and toxicity of bottom sediments in the reservoir Zeslawice, J. Elementol. 11(3): 367-377.

Kanclerz J., 2005, Wpływ stawów rybnych (karpiowych) na jakość wód odpływających ze zlewni (The impact of carp fish ponds on quality of outflow water from the catchment), Zesz. Nauk. Wydz. Budow. Inż. Środ. Koszalin 22: 823-832 (in Polish, English summary).

Knösche R., Schreckenbach K., Pfeifer M., Weissenbach H., 2000, Balances of phosphorus and nitrogen in carp ponds, Fish. Manag. Ecol. 7: 15-22.

Koc J., Duda M., 2009, The role of storage reservoirs in reducing calcium migration from agricultural catchments. J. Elementol. 14(3): 467-476.

Kosturkiewicz A., Muratowa S., 1993,Wpływ stawów rybnych na jakość wód (The effect of fishponds on water quality), Rocz. AR Poznań, Melior. Inż. Środ. 12: 51-63 (in Polish, English summary).
Licznar M, Licznar S.E., Licznar P., Żmuda R., 2005, Właściwości osadów dennych cieku Mielnica (Properties of the Mielnica watercourse bottom sediments), Acta Agrophys. 5(2): 345-355 (in Polish, English summary).

Marek J., 1989, Metale ciężkie w osadach dennych rzek zlewni Baryczy (Heavy metals in the bottom sediments of rivers belonging to the Barycz catchment area), Ochr. Środ. 2(39): 31-34 (in Polish, English summary).

Orlik T., Obroślak R., 2005, Analiza jakości wód w stawie rybnym w zlewni rzeki Giełczwi (Analysis of water quality in fish pond in eroded basin of the Giełczew River), Acta Agrophys. 5(3): 705-710 (in Polish, English summary).

Sapek B., 2001, Zagadnienie potasu w świetle oddziaływania rolnictwa na środowisko (Problem of potassium in aspect of agricultural impact of the environment), Zesz. Probl. Post. Nauk. Rol. 476: 281-292 (in Polish, English summary).

Schendel E.K., Nordstrom S., Lavculich L.M., 2004, Floc and sediment properties and their environmental distribution from a marine fish farm, Aquaculture Research 35(5): 483-493.

Skwierawski A., 2003, Skład chemiczny osadów dennych małych zbiorników wodnych jako odzwierciedlenie nasilenia procesów antropopresji w krajobrazie rolniczym (Chemical composition of bottom sediments of small water reservoirs as the reflection of anthropopressure processes in agricultural landscape), Chem. Inż. Ekol. 10(S1):159-169 (in Polish, English summary).

Szymański D., Dunalska J., Łopata M., Bigaj I., Zieliński R., 2012, Characteristics of bottom sediments of Lake Widryńskie, Limnol. Rev. 12(4): 205-210.

Szyperek U., 2005a, Wpływ zagospodarowania zlewni na skład chemiczny osadów dennych oczek wodnych. Cz. I. Zawartość i akumulacja azotu, fosforu i potasu (Efect of land use on chemical composition of bottom sediments in ponds. Part II. Concentration and accumulation of nitrogen, phosphorus and potassium), J. Elementol. 10(2): 411-420 (in Polish, English summary).

Szyperek U., 2005b, Wpływ zagospodarowania zlewni na skład chemiczny osadów dennych oczek wodnych. Cz. II. Zawartość i akumulacja sodu, magnezu i wapnia (Efect of land use on chemical composition of bottom sediments in ponds. Part II. Concentration and accumulation of sodium, magnesium and calcium), J.Elementol.10(2): 421-426 (in Polish, English summary). 